\title{
Application of Statistical Methods for Analysis of Agricultural Runoff Monitoring Data
}

\author{
Ainis Lagzdins, Latvia University of Agriculture, Viesturs Jansons, Latvia University of Agriculture
}

\begin{abstract}
The paper presents a study on water quality concerning nutrients in relation to the hydrological and meteorological conditions in three agricultural catchments in Latvia. Statistical analysis, i.e., descriptive statistics, Kolmogorov-Smirnov test, MannWhitney U test, Spearman's Rank-Order correlation and cumulative probability function has been used to quantify relationships between variables. Results of the study could be used to evaluate the impact of agricultural intensity on water quality.
\end{abstract}

Keywords - Agriculture, monitoring, nutrients, statistical analysis.

\section{INTRODUCTION}

In the Baltic Sea catchment area, the major anthropogenic source of waterborne nitrogen $\left(\mathrm{N}_{\text {tot }}\right)$ and a significant source of phosphorus $\left(\mathrm{P}_{\text {tot }}\right)$ are diffuse inputs. They constitute $71 \%$ of the nitrogen and $44 \%$ of the phosphorus load in the surface waters within the catchment area. Moreover, agriculture and managed forestry are responsible for the most of the waterborne diffuse pollution that reaches Baltic Sea agriculture alone contributed to about $80 \%$ of the $\mathrm{N}_{\text {tot }}$ diffuse load. Excessive amounts of nutrients can lead to eutrophication and cause accelerated growth of algae and plants, often resulting in undesirable effects [1]. In the future a reduction of nutrient loadings has to be achieved through proper implementation of national action plans and HELCOM recommendations, as well as through the implementation of European Union directives, such as the Water Framework Directive [2] and the Nitrates Directive [3].

To assess the impact of agriculture on water quality, monitoring of agricultural runoff was implemented in Latvia since 1994. Cooperation with the Nordic countries promoted the establishment of a network of monitoring stations (Berze, Mellupite, Vienziemite) with hydraulic measurement structures and recording equipment. The monitoring includes measurements in several spatial scales, i.e., small catchment and drainage fields. The study catchments vary in size from 368 to 960 ha and all of them are dominated by arable land that mainly is tile-drained. Land in drainage fields is used for arable crops. The impacts from point sources such as scattered households or animal farms can be considered as negligible.

Nutrient leaching is known to be strongly dependent on hydrology, which is influenced by seasonal patterns of meteorological conditions $[4,5,6]$, therefore, monitoring data, e.g., $\mathrm{N}_{\text {tot }}$ and $\mathrm{P}_{\text {tot }}$ concentrations, water discharge, precipitation and air temperature were chosen for statistical analysis. The paper presents data collected during the period 1995-2008.

The main objectives of the study presented in this paper were: (i) to analyze water quality data $\left(\mathrm{N}_{\text {tot }}\right.$ and $\left.\mathrm{P}_{\text {tot }}\right)$ obtained under agricultural practices with different intensity; (ii) to evaluate the relationship between water discharge and precipitation data; and (iii) to compare $\mathrm{N}_{\text {tot }}$ and $\mathrm{P}_{\text {tot }}$ concentrations between spatial scales within one monitoring site and between different monitoring sites.

\section{MATERIALS AND METHODS}

\section{A. Site description}

Three small catchments and drainage fields (Berze, Mellupite and Vienziemite) are located in different parts of Latvia and represent regions with various meteorological conditions, soils, slopes and farming intensity.

The Berze monitoring site is situated in the central part of Latvia and can be characterized with relatively intensive crop production in comparison with the present farming conditions in Latvia. Fertilizer and manure application in some fields has reached $160 \mathrm{~kg} \mathrm{~N} \mathrm{ha}^{-1}$ year $^{-1}$. The soil type within the catchment is silt clay loam according to FAO [7] classification that is productive soil for agricultural activities. The landscape in this area is flat.

The Mellupite catchment represents the western part of country and the average farming situation that might be typical for the present agriculture in Latvia. The average use of mineral fertilizers and manure ranges from 10 to $40 \mathrm{~kg} \mathrm{~N}^{-1}$ year $^{-1}$. The main soil type in the catchment is loam.

The Vienziemite monitoring stations are located in the north-eastern part of Latvia and are a typical example of low input agricultural land use and can be used as reference site for water quality assessment. Almost no fertilizers (only $4-5 \mathrm{~kg}$ $\mathrm{N} \mathrm{ha}^{-1}$ year $^{-1}$ ) are applied in this study site. Soil type of this area is sandy loam which is a less favorable soil for agriculture. The landscape in the Vienziemite catchment is rather hilly for Baltic conditions. The main characteristics of the monitoring sites are presented in Table I.

The flow measurements in monitoring sites were based on fixed measurement structures and automatic data and sampling equipment for continuous water level registration and water sampling. Composite water samples were collected monthly based on a flow proportional sampling procedure in Berze and Mellupite, manually water samples was taken in Vienziemite. The number of analyzed water samples varies among monitoring sites and scales because sometimes monitored streams dry out during the summer time. Analysis of water samples was carried out in laboratories according to Latvian Standard methods for total N [8] and total P [9]. 
TABLE I

MAIN CHARACTERISTICS OF MONITORING SITES

\begin{tabular}{|c|c|c|c|c|c|c|}
\hline Monitoring site & Monitoring scale & Location of monitoring points & $\begin{array}{l}\text { Area, } \\
\text { ha }\end{array}$ & Arable land, \% & Flow measurement structure & Soil \\
\hline \multirow{2}{*}{ Berze } & Small catchment & $\begin{array}{l}\text { Latitude } 56^{\circ} 42^{\prime} 11.62^{\prime \prime} \mathrm{N} \\
\text { Longitude } 23^{\circ} 22^{\prime} 46.68^{\prime \prime} \mathrm{E}\end{array}$ & 368 & 98 & Modified Crump V-weir & \multirow{2}{*}{ Silt clay loam } \\
\hline & Drainage field & $\begin{array}{l}\text { Latitude } 56^{\circ} 42^{\prime} 67.57^{\prime \prime} \mathrm{N} \\
\text { Longitude } 23^{\circ} 22^{\prime} 72.82^{\prime \prime} \mathrm{E}\end{array}$ & 77 & 100 & Triangular weir & \\
\hline \multirow{2}{*}{ Mellupite } & Small catchment & $\begin{array}{l}\text { Latitude } 56^{\circ} 29^{\prime} 77.90^{\prime \prime} \mathrm{N} \\
\text { Longitude } 22^{\circ} 14^{\prime} 12.53^{\prime \prime} \mathrm{E}\end{array}$ & 960 & 69 & Crump weir & \multirow{2}{*}{ Loam } \\
\hline & Drainage field & $\begin{array}{l}\text { Latitude } 56^{\circ} 29^{\prime} 68.64^{\prime \prime} \mathrm{N} \\
\text { Longitude } 22^{\circ} 13^{\prime} 67.13^{\prime \prime} \mathrm{E}\end{array}$ & 12 & 100 & Triangular weir & \\
\hline \multirow{2}{*}{ Vienziemite } & Small catchment & $\begin{array}{l}\text { Latitude } 57^{\circ} 08^{\prime} 12.91^{\prime \prime} \mathrm{N} \\
\text { Longitude } 25^{\circ} 54^{\prime} 29.01 " \mathrm{E}\end{array}$ & 592 & 78 & Combined profile weir & \multirow{2}{*}{ Sandy loam } \\
\hline & Drainage field & $\begin{array}{l}\text { Latitude } 57^{\circ} 06^{\prime} 35.44^{\prime \prime} \mathrm{N} \\
\text { Longitude } 25^{\circ} 55^{\prime} 41.55^{\prime \prime} \mathrm{E}\end{array}$ & 67 & 100 & Triangular weir & \\
\hline
\end{tabular}

\section{B. Statistical analysis}

Descriptive statistics (e.g., maximum, minimum, mean, median, skewness and quartiles) was used in the initial phase of a statistical analysis to describe the basic features of the data in a study. This type of analysis was performed for precipitation, air temperature, discharge and $\mathrm{N}_{\text {tot }}$ and $\mathrm{P}_{\text {tot }}$ concentration data.

The Kolmogorov-Smirnov test can be used $[10,11,12]$ to test normality of water quality, discharge and meteorological data. If the significance level ( $\mathrm{p}$ value) is less than 0.05 , then the data cannot be considered as normally distributed, and if the p-value is greater than 0.05 , there is insufficient evidence to suggest the distribution normal.

Nonparametric tests (e.g., chi-square, Spearman, MannWhitney) have fewer assumptions and often can be used when the assumptions of a parametric test are violated. For example, they do not require normal distribution of variables or homogeneity of variances [13].

Spearman's rank correlation procedure was used to identify monotonic (but not necessarily linear) correlations among constituents, providing a measure of the intensity of association between two variables. Spearman's correlation coefficient $\left(r_{s}\right)$ is the linear correlation coefficient computed on the ranks of data instead of actual values. This coefficient ranges from -1 to 1 ; a negative coefficient indicates that the higher ranks of one variable are related to the lower ranks of the other variable. The closer the absolute value of $r_{s}$ is to 1 , the greater is the correlation between the two variables. A small $r_{s}$ value, however, can still be significant, depending on the associated $\mathrm{p}$ value. If this $\mathrm{p}$ value is less than the significance level $(\mathrm{p}<0.05)$, then the null hypothesis of no correlation (or $r_{s}=0$ ) is rejected, and the correlation coefficient computed is considered statistically significant [14].

The Mann-Whitney U-test was used to compare means of two independent data sets. The test was applied to compare nutrient concentrations between the drainage field and the small catchment within one monitoring site. The comparison of $\mathrm{N}$ and $\mathrm{P}$ data between different study sites monitoring scales was done as well. Significance level ( $p$ value) helps to decide whether or not the means of two data sets are equal. If $p$ value is less than 0.05 than the difference between data sets is significant.

Probability functions could be used to represent a random variable, e.g., nutrients concentrations, water discharge, meteorological conditions, and to determine the probability of occurrence. A number of probability functions like cumulative, normal, empirical have been used in hydrological, climate and water quality studies [12].

The statistics were carried out using the SPSS software, version 15.0, and STATGRAPHICS Centurion XV.

\section{RESULTS AND DISCUSSION}

\section{A. Descriptive statistics of meteorological conditions}

Latvia is situated in a humid and moderately mild climatic region where rainfall exceeds evaporation, resulting in percolation losses from the soil during the spring and autumn [15]. Long-term records at the nearest meteorological stations indicate the differences in meteorological conditions. Observations were carried out by the Latvian Environment, Geology and Meteorology Centre. The results of air temperature and precipitation daily and annual data analysis for the period 1995-2008, along with the 60-year normals (1948-2008) are presented in Table II. Descriptive statistics of meteorological data shows that during the study period warmest and driest conditions were at the Berze site compared to other catchments, meanwhile in Vienziemite - the coldest and wettest. The mean daily precipitation in Berze was $1.58 \mathrm{~mm}$, in Mellupite $1.76 \mathrm{~mm}$ and in Vienziemite $1.95 \mathrm{~mm}$. The lowest mean annual rainfall during the years 1995-2008 was in Berze (578.6 mm), while in Mellupite $641.2 \mathrm{~mm}$ and in Vienziemite $711.2 \mathrm{~mm}$ which is quite close to 60 -year normals for the regions.

The mean annual air temperature during the observation period was higher on the Zemgale plain (Berze $7.54^{\circ} \mathrm{C}$ ) than on the Vadakste plain (Mellupite $6.42^{\circ} \mathrm{C}$ ) and on the Vidzeme highland (Vienziemite $5.66^{\circ} \mathrm{C}$ ). If these values compare with 60 -year normals it may be concluded that temperature has increasing trend which varies from $0.49^{\circ} \mathrm{C}$ up to $1.41^{\circ} \mathrm{C}$. 
TABLE II

DESCRIPTIVE STATISTICS OF PRECIPITATION AND AIR TEMPERATURE DATA

\begin{tabular}{|l|l|l|l|l|l|l|}
\hline Monitoring site & Berze & Mellupite & Vienziemite & Berze & Mellupite & Vienziemite \\
\hline Statistics & \multicolumn{3}{|c|}{ Precipitation, mm } & \multicolumn{3}{c|}{ Air temperature, ${ }^{\mathbf{C}}$ C } \\
\hline N & 5114 & 5114 & 5114 & 5114 & 5114 & 5114 \\
\hline Daily mean & 1.58 & 1.76 & 1.95 & 7.59 & 6.45 & 5.62 \\
\hline Daily median & 0.00 & 0.00 & 0.20 & 7.48 & 6.50 & 5.70 \\
\hline Daily maximum & 46.10 & 57.40 & 67.60 & 27.44 & 26.40 & 25.97 \\
\hline Daily quartiles 25 & 0.00 & 0.00 & 0.00 & 0.89 & 0.10 & -0.78 \\
\hline \multicolumn{1}{|c|}{50} & 0.00 & 0.00 & 0.20 & 7.48 & 6.50 & 5.70 \\
\hline \multicolumn{1}{|c|}{75} & 1.60 & 1.60 & 2.20 & 15.15 & 13.92 & 13.53 \\
\hline $\begin{array}{l}\text { Annual mean 1995 } \\
\text { - 2008 }\end{array}$ & 578.6 & 641.2 & 711.2 & 7.54 & 6.42 & 5.66 \\
\hline $\begin{array}{l}\text { Annual mean 1948 } \\
\text { - 2008 }\end{array}$ & 569.3 & 649.7 & 725.9 & 6.31 & 5.93 & 4.93 \\
\hline
\end{tabular}

The warmer conditions in the spring secure a more favorable environment for the faster development of plants, longer positive temperature in the autumn extend the growing season of plants. During the vegetation period when the air temperature is above + $5^{\circ} \mathrm{C}$, the potential risks for enhanced nutrient leaching are reduced due to $\mathrm{N}$ and $\mathrm{P}$ uptake by agricultural crops and aquatic plants [16].

\section{B. Descriptive statistics of discharge data}

There are several processes that influence water discharge: precipitation in the drainage area, storage of water in the soil (texture, infiltration rate, etc.) and evapotranspiration rate $[12,17$, 18]. The influence of the first two above mentioned processes is discussed in this study.

Descriptive statistics of discharge data are presented in Table III. During the study period, the highest mean daily water discharge within the catchment scale was measured in the Vienziemite monitoring site $\left(0.76 \mathrm{~mm} \mathrm{day}^{-1}\right)$, medium in Mellupite $0.61 \mathrm{~mm} \mathrm{day}^{-1}$, while the lowest in Berze $(0.43 \mathrm{~mm}$ day $^{-1}$ ). A similar pattern of water discharge was found in the drainage field monitoring scale.

The maximum daily discharge was observed in the Vienziemite catchment $\left(41.60 \mathrm{~mm} \mathrm{day}^{-1}\right)$ and it was several times higher than in Berze (16.24 mm day $\left.{ }^{-1}\right)$ and Mellupite $(13.36 \mathrm{~mm}$ $\left(\mathrm{day}^{-1}\right)$. The reasons for these maximum levels vary. In the Berze catchment, the maximum discharge was caused by snowmelt in April of 1996 when the air temperature for 9 days was above zero. In Mellupite and Vienziemite, the maximum discharge occurred after heavy rainfall, $60.3 \mathrm{~mm}$ of precipitation within 4 days in May of 1997 and $68.3 \mathrm{~mm}$ within 2 days the end of April of 2001, respectively.

The mean annual discharge during the observation period ranges from $156.55 \mathrm{~mm}$ in the Berze catchment to $279.38 \mathrm{~mm}$ in Vienziemite. The results show that the main water discharge occurs during the rainy period in the fall and spring flood (from October to May), while during the summer months, discharge is low and stable.

TABLE III

DESCRIPTIVE STATISTICS OF DISCHARGE DATA

\begin{tabular}{|l|l|l|l|l|l|l|}
\hline Monitoring site and scale & $\begin{array}{l}\text { Berze } \\
\text { catchment }\end{array}$ & $\begin{array}{l}\text { Berze } \\
\text { drainage field }\end{array}$ & $\begin{array}{l}\text { Mellupite } \\
\text { catchment }\end{array}$ & $\begin{array}{l}\text { Mellupite } \\
\text { drainage field }\end{array}$ & $\begin{array}{l}\text { Vienziemite } \\
\text { catchment }\end{array}$ & $\begin{array}{l}\text { Vienziemite } \\
\text { drainage field }\end{array}$ \\
\hline Statistics & q, mm & q, mm & q, mm & q, mm & q, mm \\
\hline N & 5114 & 5114 & 5114 & 5114 & 5114 \\
\hline Mean & 0.43 & 0.43 & 0.61 & 0.64 & 5114 \\
\hline Median & 0.10 & 0.08 & 0.21 & 0.17 & 0.76 & 0.27 \\
\hline Max & 16.24 & 16.13 & 13.36 & 14.26 & 0.71 \\
\hline Quartiles $25 \%$ & 0.01 & 0.000 & 0.05 & 0.01 & 41.60 \\
\hline $50 \%$ & 0.10 & 0.08 & 0.21 & 0.17 & 0.05 \\
\hline Annual mean $1995-2008$ & 156.55 & 156.20 & 0.45 .32 & 0.02 \\
\hline
\end{tabular}


There is clear evidence that the water discharge differences between monitored sites can be explained by the precipitation rate in a particular study site, for example higher rainfall in Vienziemite leads to higher water discharge. In addition, soil properties within specific regions regulate water discharge. Sandy soils contain less water at field capacity than clay or silt loam soils and leaching is therefore induced more quickly in lighter soils. Poorly drained silt clay loam soil in the Berze catchment can store more water longer therefore discharge respond slowly, whereas well drained sandy loam soil in Vienziemite promotes faster water infiltration through soil profile that results in high discharge volumes.

\section{Descriptive statistics of nutrient concentration data}

In several investigations [11, 16, 19, 20, 21, 22] it has been found that water discharge as a transport pathway must be taken into account when analyzing trends in nutrient concentrations. The $\mathrm{N}_{\text {tot }}$ and $\mathrm{P}_{\text {tot }}$ concentration data showed high variability over time, study sites and monitoring scales.

The specific character of monitoring scales has to be taken into account when the analysis of catchment and drainage water quality is performed. Discharge from drainage fields in comparison with catchment scale can be considered as soil solution where retention processes is rather low.

Plants generally take up $\mathrm{N}$ as $\mathrm{NO}_{3}{ }^{-}$, or $\mathrm{NH}_{4}{ }^{+}$from the soil solution [23]. These forms of $\mathrm{N}$ are leaching out in appreciable amounts by water passing through the soil profile. This is because there is no significant adsorption of soluble forms of $\mathrm{N}$ on soil particles [22, 24, 25]. The export from small agricultural catchments consists mostly of dissolved inorganic constituents and smaller amounts of organic $\mathrm{N}$ [26]. Thus $\mathrm{NO}_{3}^{-}-\mathrm{N}$ contributes on average $90 \%$ of the annual total $\mathrm{N}$ export in the Berze and Mellupite drainage field scale and in catchment scale $79 \%$ and $62 \%$, respectively. In both monitoring scales of Vienziemite $\mathrm{NO}_{3}{ }^{-}$ $-\mathrm{N}$ and $\mathrm{N}_{\text {tot }}$ proportion is less significant $-45 \%$.

The studies carried out in Finland and USA [27, 28] shows that phosphorus is transported in dissolved and particulate forms. Particulate $\mathrm{P}$ includes $\mathrm{P}$ sorbed by soil particles and organic matter eroded during flow events and constitutes the major proportion of $\mathrm{P}$ transported from cultivated lands (60-90\%). Amounts of $\mathrm{P}$ transported from catchment are a function of catchment hydrology, in terms of when and where surface runoff occurs, soil $\mathrm{P}$ content, and amount $\mathrm{P}$ added as fertilizer or manure. This assumes that in most cases, $\mathrm{P}$ export from catchment occurs in surface rather than subsurface runoff, although it is recognized that in some regions, notably Florida, Western Australia and the Netherlands, most $\mathrm{P}$ is transported in drainage waters [21].

Obtained stream water concentration data clearly indicates impact of agricultural intensity on water quality. The highest mean nutrient concentrations was observed in the Berze catchment $\left(\mathrm{N}_{\text {tot }} 8.37 \mathrm{mg} \mathrm{l}^{-1}, \mathrm{P}_{\text {tot }} 0.167 \mathrm{mg} \mathrm{l}^{-1}\right)$, in the Mellupite mean concentration of $\mathrm{N}_{\text {tot }}$ was $3.70 \mathrm{mg} \mathrm{l}^{-1}$ and $\mathrm{P}_{\text {tot }} 0.086 \mathrm{mg} \mathrm{l}^{-1}$, while in the Vienziemite catchment the lowest concentrations were detected, $\mathrm{N}_{\text {tot }} 1.72 \mathrm{mg} \mathrm{l}^{-1}$ and $\mathrm{P}_{\text {tot }} 0.042 \mathrm{mg} \mathrm{l}^{-1}$ (Table IV).

TABLE IV

DESCRIPTIVE STATISTICS NUTRIENT CONCENTRATION DATA

\begin{tabular}{|c|c|c|c|c|c|c|c|c|c|c|c|c|}
\hline \multirow{2}{*}{$\begin{array}{l}\text { Monitoring site } \\
\text { and scale }\end{array}$} & \multicolumn{2}{|c|}{ Berze_Ca } & \multicolumn{2}{|c|}{ Berze_Dr } & \multicolumn{2}{|c|}{ Mellupite_Ca } & \multicolumn{2}{|c|}{ Mellupite_Dr } & \multicolumn{2}{|c|}{ Vienziemite_Ca } & \multicolumn{2}{|c|}{ Vienziemite_Dı } \\
\hline & $\begin{array}{l}\mathrm{N}_{\mathrm{tot}} \\
\mathrm{mg} \mathrm{l}^{-1}\end{array}$ & $\begin{array}{l}\mathrm{P}_{\mathrm{tot}} \\
\mathrm{mg} \mathrm{l}^{-1}\end{array}$ & $\begin{array}{l}\mathrm{N}_{\text {tot }} \\
\mathrm{mg} \mathrm{l}^{-1}\end{array}$ & $\begin{array}{l}\mathrm{P}_{\mathrm{tot}}, \\
\mathrm{mg} \mathrm{l}^{-1}\end{array}$ & $\begin{array}{l}\mathrm{N}_{\mathrm{tot}}, \\
\mathrm{mg} \mathrm{l}^{-1}\end{array}$ & $\begin{array}{l}\mathrm{P}_{\text {tot }} \\
\mathrm{mg} \mathrm{l}^{-1}\end{array}$ & $\begin{array}{l}\mathrm{N}_{\text {tot }} \\
\mathrm{mg} \mathrm{l}^{-1}\end{array}$ & $\begin{array}{l}\mathrm{P}_{\mathrm{tot}} \\
\mathrm{mg} \mathrm{l}^{-1}\end{array}$ & $\begin{array}{l}\mathrm{N}_{\mathrm{tot}}, \\
\mathrm{mg} \mathrm{l}^{-1}\end{array}$ & $\begin{array}{l}\mathrm{P}_{\text {tot }} \\
\mathrm{mg} \mathrm{l}^{-1}\end{array}$ & $\begin{array}{l}\mathrm{N}_{\mathrm{tot}} \\
\mathrm{mg} \mathrm{l}^{-1}\end{array}$ & $\begin{array}{l}\mathrm{P}_{\mathrm{tot}}, \\
\mathrm{mg} \mathrm{l}^{-1}\end{array}$ \\
\hline $\mathrm{N}$ & 157 & 157 & 145 & 145 & 160 & 160 & 132 & 132 & 176 & 176 & 169 & 169 \\
\hline Mean & 8.37 & 0.167 & 12.05 & 0.056 & 3.70 & 0.086 & 7.30 & 0.074 & 1.72 & 0.042 & 1.64 & 0.045 \\
\hline Median & 7.64 & 0.116 & 10.20 & 0.030 & 3.30 & 0.051 & 7.00 & 0.054 & 1.50 & 0.030 & 1.39 & 0.035 \\
\hline Minimum & 0.90 & 0.018 & 1.90 & 0.010 & 0.53 & 0.004 & 1.60 & 0.005 & 0.43 & 0.009 & 0.32 & 0.006 \\
\hline Maximum & 29.50 & 2.126 & 102.7 & 0.417 & 16.30 & 0.709 & 16.80 & 1.106 & 7.50 & 0.712 & 7.50 & 0.433 \\
\hline Skewness & 1.00 & 6.293 & 6.07 & 2.766 & 1.44 & 2.980 & 0.69 & 7.330 & 1.96 & 9.318 & 2.62 & 5.414 \\
\hline Quartiles 25 & 4.50 & 0.074 & 7.36 & 0.021 & 1.60 & 0.027 & 5.60 & 0.025 & 1.00 & 0.019 & 0.90 & 0.022 \\
\hline 50 & 7.64 & 0.116 & 10.20 & 0.030 & 3.30 & 0.051 & 7.00 & 0.054 & 1.50 & 0.030 & 1.39 & 0.035 \\
\hline 75 & 10.8 & 0.190 & 14.70 & 0.064 & 5.08 & 0.098 & 8.78 & 0.093 & 2.13 & 0.045 & 2.00 & 0.056 \\
\hline
\end{tabular}

The mean nutrient concentrations at the drainage field scale represent the same influence of applied mineral and organic fertilizers as in small catchments. Mean concentrations of $\mathrm{N}_{\text {tot }}$ in Berze (12.05 $\left.\mathrm{mg}^{-1}\right)$ and Mellupite $\left(7.30 \mathrm{mg} \mathrm{l}^{-1}\right)$ are several times higher than in Vienziemite $\left(1.64 \mathrm{mg} \mathrm{l}^{-1}\right)$. Whereas concerning $\mathrm{P}_{\text {tot }}$ concentrations, such differences are not observed, $\mathrm{P}_{\text {tot }}$ in Berze $0.056 \mathrm{mg} \mathrm{l}^{-1}$, in Mellupite $0.074 \mathrm{mg} \mathrm{l}^{-1}$ and in Vienziemite 0.045 $\mathrm{mg} \mathrm{l}^{-1}$.
The maximum value of $\mathrm{N}_{\mathrm{tot}}$ was fixed in the fall of 2006 in the Berze drainage field $\left(102.70 \mathrm{mg}^{-1}\right)$. This extreme value can be explained by the start of water discharge in tile drains after the dry period of summer. The maximum concentration of $\mathrm{P}_{\text {tot }}$ as well was obtained in Berze $\left(2.126 \mathrm{mg} \mathrm{l}^{-1}\right)$, this time in small catchment scale. The possible reason for this extreme can be sugar beet harvesting and land tillage in combination with precipitation under high soil moisture conditions. 
Hydrologic and water quality data are typically skewed, meaning that data sets are not symmetric around the mean or median, with extreme values extending out longer in one direction. When extreme values extend the right tail of the distribution it is positive skewness, in this case most of values are low, when the tail extends to the left, is called negative skew and majority of values is high [29]. Within all study sites and scales skewness coefficients that represent $\mathrm{N}_{\text {tot }}$ concentration data are insignificantly positively skewed which means that most of values are dispersed around mean value. At the same time, $\mathrm{P}_{\text {tot }}$ concentrations are importantly positively skewed, in this case a majority of concentrations are low with some outliers, for instance skewness coefficient for the Vienziemite catchment concentrations is 9.318 .

The time series of small catchment $\mathrm{N}_{\text {tot }}$ concentrations indicated an upward trend at two study sites (Berze and Mellupite) where agricultural activities are crop production oriented. Low intensity farming practice in Vienziemite results in persistent invariable trend of concentrations (Fig. 1).

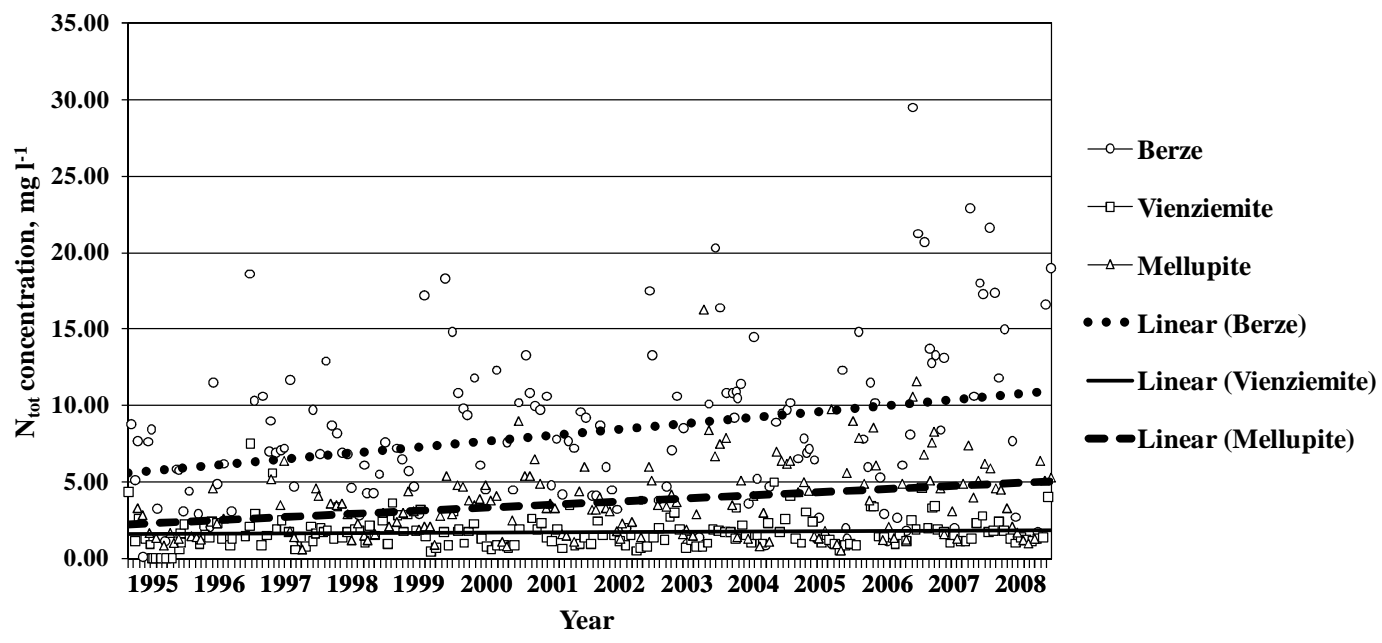

Fig. 1. Time series of $\mathrm{N}_{\text {tot }}$ concentrations in study catchments, 1995 - 2008.

It has been reported [30] that $\mathrm{N}_{\text {tot }}$ concentrations and leaching losses differ, depending on the scale of measurement, concentrations decrease when the scale of measurement increases. A decrease of $\mathrm{N}_{\text {tot }}$ concentration within the catchment scale in comparison with the drainage field is mainly related with retention processes in streams, i.e., denitrification, organic matter burial in sediments, sediment sorption, and plant and microbial uptake. This study approved the above mentioned statement except at Vienziemite site where $\mathrm{N}_{\text {tot }}$ and $\mathrm{P}_{\text {tot }}$ concentrations in both scales vary negligible. $\mathrm{P}_{\text {tot }}$ concentrations in Berze and Mellupite are higher in catchment scale due to surface runoff transport of additional $\mathrm{P}$ in eroded matter. $\mathrm{P}$ in rivers and streams although can be retained by adsorption onto streambed sediments, sedimentation, and via uptake by algae and aquatic macrophytes [16].

\section{The Kolmogorov-Smirnov test}

The Kolmogorov-Smirnov test is successfully used by investigators to examine the distributions of data sets $[10,11,12$, 29]. In our study tests detected an abnormal distribution of precipitation, air temperature, and water discharge data at significance level $\alpha=0.05$. Normality within nutrient data sets was approved in case of Berze $(\alpha=0.196)$, Mellupite $(\alpha=0.073)$ catchment and Mellupite drainage field $(\alpha=0.305) \quad \mathrm{N}_{\text {tot }}$ concentration data. Nonparametric tests can applied on data sets that did not show a normal distribution and if compare normal and non-normal distribution data.

\section{E. Spearman's correlation coefficients}

Spearman's correlation coefficients $\left(\mathrm{r}_{\mathrm{s}}\right)$ between precipitation and discharge show a very weak relationship in all study sites. In the small catchment of Berze, the determined $\mathrm{r}_{\mathrm{s}}$ was $0.111(\mathrm{p}=$ $0.00)$, in drainage field $r_{s}=0.055(p=0.00)$, in Mellupite small catchment $r_{s}=0.121(p=0.00)$, in drainage field $r_{s}=0.139(p=$ $0.00)$, and in Vienziemite catchment $r_{s}=0.161(p=0.00)$, in drainage field $r_{s}=0.161(p=0.00), p$ value indicates that the given correlation coefficients are statistically reliable. Factors that affect redistribution of moisture, and thus field capacity, i.e., soil texture, type of clay, organic matter content, depth of wetting and antecedent moisture, presence of impeding layers, and evapotranspiration, have to be considered [18]. For example, clay soils in Berze hold more water longer than sandy soils in Vienziemite. In further studies of relationships between precipitation and discharge, attention should be paid on the time that is needed to reach field capacity in specific study sites. In other words, how fast hydrology responds to rainfall events.

\section{F. The Mann-Whitney U test}

The Mann-Whitney U test can be used when it is not possible to make the assumptions required for parametric test, so it may be desirable to use a non-parametric test that can be applied under a less restrictive set of assumptions [12]. The test was applied in several other water quality studies $[10,11,14]$. The significance level 0.05 is used to determine differences between two data sets. The results of this test shows that differences between the Berze 
site drainage field and catchment $\mathrm{N}_{\text {tot }}$ and $\mathrm{P}_{\text {tot }}$ data sets are significant, in both cases $\mathrm{p}=0.00$. Differences between drainage field and catchment concentrations are not significant in comparison to $\mathrm{P}_{\text {tot }}$ data sets in Mellupite site $(\mathrm{p}=0.57)$ that indicate simila leaching patterns of $\mathrm{P}_{\text {tot }}$ in both monitoring scales within this area. There are no significant differences in $\mathrm{N}_{\text {tot }}(\mathrm{p}=0.17)$ and $\mathrm{P}_{\text {tot }}(\mathrm{p}=0.06)$ concentrations within monitoring scales at the Vienziemite site.

On comparing nutrient concentrations between spatial scales within different monitoring sites, it can be summarized that concentrations vary widely with one exception, $\mathrm{P}_{\text {tot }}$ concentrations in Berze and Vienziemite drainage fields are not significantly different $(p=0.97)$. Generally, results show that the intensity of agricultural practice increase the variability of nutrient concentrations between monitoring scales.

\section{G. Normal probability distribution plots}

Normal probability distribution plots can be used in the analysis of meteorological, discharge and water quality data. In this study an example of analysis of yearly precipitation data of the Mellupite monitoring site is discussed and presented in Fig. 2.

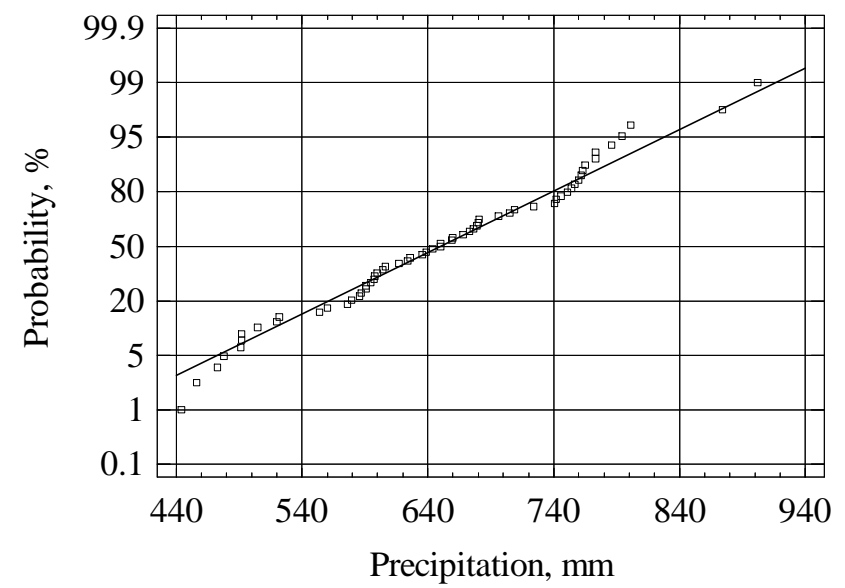

Fig. 2. Normal probability distribution of the yearly precipitation of Mellupite monitoring site, $1948-2008$.

The evaluation of precipitation data is possible if one uses the gradation of probability percentage. For instance, $10 \%$ of probability represents dry year, 25\% - semi dry year, 50\% average or normal year, $75 \%$ - semi wet year and $90 \%$ - wet year. The annual mean precipitation (641.21 or approximately $50 \%$ of probability) during the research period (1995-2008) can be evaluated as a normal or average value for the Mellupite site. Although, during the study period dry year in 2005 (472.8 mm) and wet year in $2001(773.2 \mathrm{~mm})$ is recorded.

\section{CONCLUSIONS}

The main conclusions that can be drawn from the present results are as follows:

- Obtained stream water concentration data clearly indicates the impact of agricultural intensity on water quality. The highest mean nutrient concentrations during the study period within the catchment scale were observed in Berze $\left(\mathrm{N}_{\text {tot }} 8.37 \mathrm{mg} \mathrm{l} \mathrm{l}^{-1}, \mathrm{P}_{\text {tot }}\right.$ $\left.0.167 \mathrm{mg} \mathrm{l}^{-1}\right)$, while the lowest in Vienziemite $\left(\mathrm{N}_{\text {tot }} 1.72 \mathrm{mg}^{-1}\right.$ and $\mathrm{P}_{\text {tot }} 0.042 \mathrm{mg} \mathrm{l}^{-1}$ ). The mean nutrient concentrations at the drainage field scale represent the same influence of applied mineral and organic fertilizers as in small catchments.

- Spearman's correlation coefficients between precipitation and discharge show a very weak relationship in all study sites and monitoring scales.

- The results show that the intensity of agricultural practices increase the variability of nutrient concentrations between monitoring scales and sites. Differences between drain field and catchment concentrations are not significant in comparison to $\mathrm{P}_{\text {tot }}$ data sets in Mellupite site $(\mathrm{p}=0.57)$ and both $\mathrm{N}_{\text {tot }}(\mathrm{p}=0.17)$ and $\mathrm{P}_{\text {tot }}$ $(\mathrm{p}=0.06)$ concentrations within the Vienziemite site. Only $\mathrm{P}_{\text {tot }}$ concentrations in the Berze and Vienziemite drainage fields are not significantly different $(\mathrm{p}=0.97)$ in comparison to the nutrient concentrations between spatial scales within different monitoring sites.

- The main explanation of the variability in nutrient concentrations and losses among study sites is the intensity of agricultural management which is human caused activity, other natural factors, i.e. meteorological conditions, water discharge, soil type and slope, can be considered as secondary.

\section{ACKNOWLEDGMENTS}

The author gratefully acknowledges the funding from EU and ESF (Agreement No. 2009/0180/1DP/1.1.2.1.2/09/ IPIA/VIAA/017 ,Support for Doctoral Studies Programme of Latvia University of Agriculture", 04.4-08/EF2.D3.25).

\section{REFERENCES}

1. HELCOM. Eutrophication in the Baltic Sea - An integrated thematic assessment of the effects of nutrient enrichment and eutrophication in the Baltic Sea region. In: Baltic Sea Environment Proceedings No. 115A, Helsinki, Finland, 2009, p. 3-11.

2. Directive 2000/60/EC of the European parliament and of the council of 23 October 2000 establishing a framework for the Community action in the field of water policy. Official Journal of the European Communities, L 327, p. 172.

3. Council Directive 91/676/EEC of 12 December 1991 concerning the protection of water against pollution caused by nitrates from agricultural sources. Official Journal of the European Communities, L 375, p. 1-8.

4. Bakhsh, A., Kanwar, R. S., Pederson, C., et. al. N-source effects on temporal distribution of $\mathrm{NO}_{3}-\mathrm{N}$ leaching losses to subsurface drainage water. Water, Air \& Soil Pollution, 2006, No. 181, p. 35-50.

5. Magner, J. A., Payne, G. A., Steffen, L. J. Drainage effects on stream nitrate-N and hydrology in south-central Minnesota (USA). Environmental Monitoring and Assessment, 2004, No. 91, p. 183-198.

6. Vuorenmaa, J., Rekolainen, S., Lepistö, A., et. al. Losses of nitrogen and phosphorus from agricultural and forest areas in Finland during the 1980s and 1990s. Environmental Monitoring and Assessment, 2002, No. 76, p. 213248.

7. FAO. Guidelines for soil profile description. Fourth edition. Food and Agriculture Organization of the United Nations, Rome, Italy, 2006. 97 p.

8. Water quality - Determination of nitrogen - Part 1: Method using oxidative digestion with peroxodisulfate. LVS EN ISO 11905-1:1998.

9. Water quality - Determination of phosphorus - Ammonium molybdate spectrometric method. LVS EN ISO 6878:2005 A/L.

10. Stenger, R., Priesack, E., Beese, F. Spatial variation of nitrate-N and related soil properties at the plot-scale. Geoderma, 2002, vol. 105, p. 259-275.

11. Van Herpe, Y., Troch, P. A. Spatial and temporal variations in surface water nitrate concentrations in a mixed land use catchment under humid temperate climatic conditions. Hydrological Processes, 2000, No. 14, p. 1328-1344.

12. von Storch, H., Zwiers, F. W. Statistical Analysis in Climate Research. Cambridge: Cambridge University Press, United Kingdom, 1999. 484 p.

13. SPSS for Introductory Statistics: Use and Interpretation (Second Edition). G.A. Morgan, N.L. Leech, G.W. Gloeckner, K.C. Barrett. Lawrence Erlbaum Associates, Mahwah, New Jersey, 2004. 211 p. 
14. Warner, K. L. Analysis of Nutrients, Selected Inorganic Constituents, and Trace Elements in Water from Illinois Community-Supply Wells, 1984-91. Water-Resources Investigations Report 99-4152, U.S. Geological Survey, Urbana, Illinois, USA, 2000. 47 p.

15. Jansons, V., Busmanis, P., Dzalbe, I., et. al. Catchment and Drainage Field Nitrogen Balances and Nitrogen Loss in Three Agriculturally Influenced Latvian Watersheds. European Journal of Agronomy, 2003, vol. 20, p. 173 179.

16. Stålnacke, P., Grimvall, A., Libiseller, C., et. al. Trends in nutrient concentrations in Latvian rivers and the response to the dramatic change in agriculture. Journal of Hydrology, 2003, vol. 283, p. 184-205.

17. Randall, G. W., Mulla, D. J. Nitrate Nitrogen in Surface Waters as Influenced by Climatic Conditions and Agricultural Practices. Journal of Environmental Quality, 2001, vol. 30, p. 337-344.

18. Ritter, W. F., Shirmohammadi, A. Agricultural nonpoint source pollution: Watershed management and hydrology. CRC Press LLC, Boca Raton, Florida, USA, 2001. 342 p.

19. Donohue, R., Davidson, W. A., Peters, N. E., et. al. Trends in total phosphorus and total nitrogen concentrations of tributaries to the SwanCanning Estuary, 1987 to 1998. Hydrological Processes, 2001, vol. 15, p. 2411-2434.

20. Armstrong, A. C., Burt, T. P. Nitrate Losses from Agricultural Land. In: Nitrate: Processes, Patterns and Management. John Wiley \& Sons Ltd. Chichester, United Kingdom, 1993, p. 239-267.

21. Sharpley, A. N., Rekolainen, S. Phosphorus in Agriculture and Its Environmental Implications. In: Phosphorus Loss from Soil to Water. CAB International, Wallingford, United Kingdom, 1997, p. 1-53.

22. McDowell, R. W., Sharpley, A. N., Kleinman, P. J. A., et. al. Hydrological Source Management of Pollutants at the Soil Profile Scale. In: Agriculture, Hydrology and Water Quality. CAB International, Wallingford, United Kingdom, 1997, p. 197-223.

23. Hatch, D., Goulding, K., Murphy, D. Nitrogen. In: Agriculture, Hydrology and Water Quality. CAB International, Wallingford, United Kingdom, 1997, p. 7-27.
24. Vinten, A. J. A., Smith, K. A. Nitrogen Cycling in Agricultural Soils. In: Nitrate: Processes, Patterns and Management. John Wiley \& Sons Ltd., Chichester, United Kingdom, 1993, p. 39-73.

25. Augsnes ilgtspējīga izmantošana un aizsardzība. O. Nikodemus, A. Kārklinšs, M. Kḷaviņš, V. Melecis. Rīga: LU Akadēmiskais apgāds, 2008. 256 p.

26. Kronvang, B., Grant, R., Laubel, A. R., et. al. Quantifying Sediment and Nutrients Pathways within Danish Agricultural Catchments. In: Agriculture, Hydrology and Water Quality. CAB International, Wallingford, United Kingdom, 1997, p. 281-301.

27. Pietilainen, O. P., Rekolainen, S. Dissolved reactive and total phosphorus load from agricultural and forested basins to surface water in Finland. Aqua Fennica, 1991, vol. 21, p. 127-136.

28. Sharpley, A. N., Smith, S. J., Jones, O. R., et. al. The transport of bioavailable phosphorus in agricultural runoff. Soil Science Society of America Journal, 1992, vol. 57, p. 1131-1137.

29. Helsel, D. R., Hirsch, R. M. Statistical Methods in Water Resources. Techniques of Water-Resources Investigations of the United States Geological Survey, U.S. Geological Survey, 2002, 510 p. [E-book] Available: http://water.usgs.gov/pubs/twri/twri4a3/

30. Deelstra, J., Abramenko, K., Vagstad, N., et. al. Hydrological Pathways, Scale Issues and Nitrogen Runoff: a Case Study in a Latvian Catchment. In: Nordic Hydrological Programme Report No. 48, Tartu, Estonia, 2004, p. 219-229.

Ainis Lagzdins, $\mathrm{PhD}$, assistant

Faculty of Rural Engineering, Latvia University of Agriculture.

Address: 19 Akademijas Street, Jelgava, LV-3001

Phone: +37163021413

E-mail: ainis.lagzdins@1lu.lv

Viesturs Jansons, prof., Dr.sc.ing.

Faculty of Rural Engineering, Latvia University of Agriculture.

Address: 19 Akademijas Street, Jelgava, LV-3001

Phone: +37163029908

e-mail: viesturs.jansons@1lu.lv

\section{Ainis Lagzdinšs, Viesturs Jansons. Statistisko metožu pielietojums lauksaimniecības noteču monitoringa datu analīzēe}

Piesārnojums ar biogēnajiem elementiem (slāpekla un fosfora savienojumi) ir viens no ūdenu kvalitāti raksturojošiem kritērijiem. Pastiprināts biogēno elementu satura pieaugums ievērojami palielina biologisko procesu intensitāti ūdenstilpēs un ūdenstecēs (eitrofikācija) un ir iemesls vairākām nevēlamām sekām. Veicot pētījumus par ūdeņu kvalitāti raksturojošo slāpekḷa un fosfora savienojumu koncentrāciju un noplūžu izmaiṇām, kā arī par hidroloǵiskajiem un meteorologiskajiem apstākḷiem, tika izmantoti Latvijas Lauksaimniecības universitātes Vides un ūdenssaimniecỉbas katedras veiktā lauksaimniecības noteču monitoringa dati, kas iegūti divos izpētes līmenos Bērzes, Mellupītes un Vienziemītes objektos laika posmā no 1995. līdz 2008. gadam. Bērzes monitoringa stacijas sateces baseins raksturo intensīvus, Mellupītes - vidēji intensīvus, bet Vienziemītes ekstensīvus lauksaimniecības apstāklıus Latvijā.

Iegūto datu analīzei izmantota aprakstošā statistika, Kolmogorova-Smirnova tests, Spearman rangu korelācija, Mann-Whitney U tests. Apkopojot aprakstošās statistikas sniegto informāciju par nokrišņu daudzumu un gaisa temperatūrām, var secināt, ka Bērzes monitoringa stacijas tuvumā ir vissiltākie un sausākie apstākḷi, turpretim Vienziemītē visvēsākie un mitrākie. Kopējā slāpekḷa un kopējā fosfora koncentrācijas vidējās vērtības izteikti ataino lauksaimniecības intensitāti pētāmajās teritorijās. Bērzē sateces baseina līmenī tās ir visaugstākās, aritmētiskais vidējais $\mathrm{N}_{\text {kop }}-8.37 \mathrm{mg} \mathrm{l}^{-1}, \mathrm{P}_{\text {kop }} 0.167 \mathrm{mg} \mathrm{l}^{-1}$, Mellupītē $\mathrm{N}_{\text {kop }}-3.70 \mathrm{mg} \mathrm{l}^{-1}$, $\mathrm{P}_{\text {kop }} 0.086$ mg l $1^{-1}$, savukārt Vienziemītē viszemākās - $\mathrm{N}_{\text {kop }} 1.72$ $\mathrm{mg} \mathrm{l}^{-1}, \mathrm{P}_{\text {kop }} 0.042 \mathrm{mg} \mathrm{l}^{-1}$

Kolmogorova-Smirnova testa rezultāti liecina, ka meteorologiskie un noteču dati neatbilst normālajam sadalījumam, atbilstība normālajam sadalījumam konstatēta Bērzes un Mellupītes mazās sateces baseina $\mathrm{N}_{\text {kop }}$ koncentrāciju datu kopām, kā arī Mellupītes drenu lauka $\mathrm{N}_{\text {kop }}$ datu kopai. Spearman rangu korelācijas analīze liecina, ka visās monitoringa stacijās un pētniecības līmeņos nokrišnu un noteces savstarpējā saistība ir neliela. Mann-Whitney U testa rezultāti norāda, ka Bērzē novēroto $\mathrm{N}_{\text {kop }}$ un $\mathrm{P}_{\text {kop }}$ koncentrāciju vērtības sateces baseinā un drenu laukā atšksiras būtiski, turpretim Mellupītes $\mathrm{N}_{\text {kop }}$ koncentrācijas, kā arī Vienziemītes $\mathrm{N}_{\text {kop }}$ un $\mathrm{P}_{\text {kop }}$ koncentrācija abos monitoringa līmeņos būtiski neatškiras.

\section{Айнис Лагздиныш, Виестурс Янсонс. Использование статистических методов в анализе данных сельскохозяйственного мониторинга стоков}

Загрязнение биогенными элементами (азота и фосфора) является одним из критериев характеризующим качество воды. Увеличение содержание питательных веществ значительно увеличивает интенсивность биологических процессов в воде (эвтрофикация) и является причиной ряда негативных последствий. В проведение исследований на характеристики качества воды по концентрации азота и фосфора и изменения стока, а также на гидрологические и метеорологические условия были использованы данные сельскохозяйственного мониторинга стоков, который реализует Кафедра по охране среды и водному хозяйству Латвийского Сельскохозяйственного университета. Данные полученны в двух разведочных уровнях в мониторных станцыях Берзе, Мелупите и Виензиемите в периоде времени с 1995 по 2008 году. Условия земледелие в Берзе можно характеризовать как интенсивные, в Мелупите средней интенсивности, в Виензиемите - экстенсивные.

В результате анализа данных использована описательная статистика, тест Kolmogorova - Smirnova, корреляция Spearman, Mann-Whitney U тест. Подводя итоги описательной статистическе насчёт информации по количестве осадков и температуры воздуха, можно сделать вывод, что по сравнению с другими станциями мониторинга вблизи Берзе самые теплые и сухие условия, в то время как вбзи Виензиемите - холодные и влажные. Средние величины общего азота и общего фосфора представляет интенсивность сельскохозяйственных районов. Средние величины в Берзе самые вышие, общий азот - $8.37 \mathrm{mg} \mathrm{l}^{-1}$, общий фосфор - $0.167 \mathrm{mg} \mathrm{l}^{-}$ , в Мелупите общий азот - $3.70 \mathrm{mg} \mathrm{l}^{-1}$, общий фосфор - $0.086 \mathrm{mg} \mathrm{l}^{-1}$, в тоже время в Виензиемите самые низкие, общий азот - $1.72 \mathrm{mg}{ }^{-1}$, общий фосфор - $0.042 \mathrm{mg}^{-1}$. Результаты Kolmogorov - Smirnov теста указывается, что метеорологические данные и данные стока нераспределены нормально, нормального распределения обнаружено в данных азота на уровне бассейнов Берзе и Мелупите, а также в данных азота на уровне дренажых водосборов Мелупите. Корреляция Sреагтап показывает, что отношения между осадками и стока евляется низкими в всех станциях мониторинга и исследованых уровнях. Результаты испытаний Мапn-Whitnеy $\mathrm{U}$ тестом показывают, что в Берзе концентрации общего азота и общего фосфора существенно отличается на уровне бассейна и дренажного поля. В тоже время концентрации общего азота в Мелупите на уровне бассейна, а также величины общего азота и общего фосфора в Виензиемите в обоих разведочных уровнях существенно неотличается. 